\title{
Control and Monitoring System for a Hydrogen Sulfide Gas Bio-filter Applied to a Hydroelectric Generation Plant
}

\author{
Erika Alexandra Niño Castillo ${ }^{1}$, Edison Torres Torrado ${ }^{2}$ and Fernando Martínez Santa ${ }^{3}$ \\ 1,2,3 Universidad Distrital, Francisco José de Caldas, Technology Faculty, Bogotá, Colombia.
}

\begin{abstract}
The aim of this article is to present the control and monitoring system implemented to the bio-filter of the El Paraíso hydroelectric generation plant, which efficiently seeks to reduce the levels of emanation of hydrogen sulfide $\mathrm{H} 2 \mathrm{~S}$, a colorless, flammable and toxic gas with a characteristic smell of "rotten eggs" produced by the use of the waters of the Bogotá river in the energy generation process. The plant has a biological filter made up of microorganisms used to remove contaminants, which require certain environmental conditions such as humidity and temperature for their development and survival. In order to address this problem, the document describes the requirements needed to implement the control and monitoring system, which make it possible to supervise and control all of the processes involved in the production and reduction of hydrogen sulfide $\mathrm{H} 2 \mathrm{~S}$. These processes include supervision and action of the air extractors, internal and external watering of the bio-filter by controlling its humidity and temperature limits, and control of foam in the stilling tank. Likewise, the operation of the systems is related to the programming of generation schedules of the units, seeking to minimize the impact of environmental conditions in the Plant and its surroundings. The contribution presented through the implementation of the Control System showed as a result an improvement in the efficiency of the bio-filter, reducing the concentrations of gas found in the bio-filter by $70 \%$ and a reduction in the explosion limits by $85 \%$, evidencing a great improvement in the surroundings of the plant, cleaning up the quality of the air.
\end{abstract}

Keywords: hydrogen sulfide (H2S), hydroelectric generation, Lower Explosive Limit (LEL), Bio-filter, PLC

\section{INTRODUCTION}

A series of hydroelectric plants with a water storage reservoir was built on the Bogotá river in Colombia. The reservoir is piped $15 \mathrm{~km}$ to the El Paraíso plant as part of a generation chain called PAGUA, which includes the El Paraíso and Guaca plants with an installed capacity of $600 \mathrm{MW}$ [1].

Wastewater from the Bogotá river arrives at the El Paraíso plant to be turbined during the generation process and is discharged to a stilling tank, where the water rests before being directed to the Guaca hydroelectric plant.
The company in charge of the plant has made an environmental commitment to mitigate the impacts that this generation process produces from the use of this wastewater; the first problem is the emanation of hydrogen sulfide by the turbination of the water. As a solution, a treatment system for those gases was incorporated by means of a bio-filter, a bioremediation technology through biological oxidation by microorganisms immobilized by a solid phase called compost, a material that must provide nutrients and moisture to the microorganisms for their development and survival [2] [3] [4], The second problem is the production of foam in the stilling tank, when the water recirculates with the presence of chemicals, creating a solution resulting in increased foam, which if not controlled with a water irrigation can overflow affecting the soil and water sources in the region of Mesitas del Colegio, Cundinamarca.

Maintaining the conditions of the compost and the low level of foam in the stilling tank is done through a sequence of processes that are currently developed manually according to the criteria of the personnel in charge of the operation of the generation units. This means that there are no automatic control variables to determine when the instrumentation should be activated or deactivated, taking into account environmental parameters and/or gas levels, temperature and humidity, operating limits that allow the operation of the compost to be maintained in good conditions and the efficient extraction of the gas, resulting in the release of air free of contaminants.

Therefore, in order to mitigate the impact caused by the uncontrolled emission of gases, mainly hydrogen sulfide $\mathrm{H} 2 \mathrm{~S}$, which emits bad odors, is flammable and one of the contaminants responsible for a significant fraction of air pollution in the world [5][6], it is necessary to incorporate a control system for the bio-filter that allows for the efficient reduction of contaminating agents generated in the hydroelectric plant and thus avoid effects on its collaborators and surrounding communities.

Therefore, a control system based on PLC was created, being one of the main components for the automation of these processes, incorporating input and output signals [7] for the supervision of the humidity and temperature ranges of the biofilter and the foam levels in the stilling tank, in which a sequence of instructions is entered according to the operation limits established in the article. 


\section{PROCESS DESCRIPTION}

The process for the removal of hydrogen sulfide and the control of foam in the tank must take into account the phases that allow the extraction of the gas from the stilling tank to the four beds of the bio-filter incorporating the corresponding control system, Fig. 1. illustrates the process.

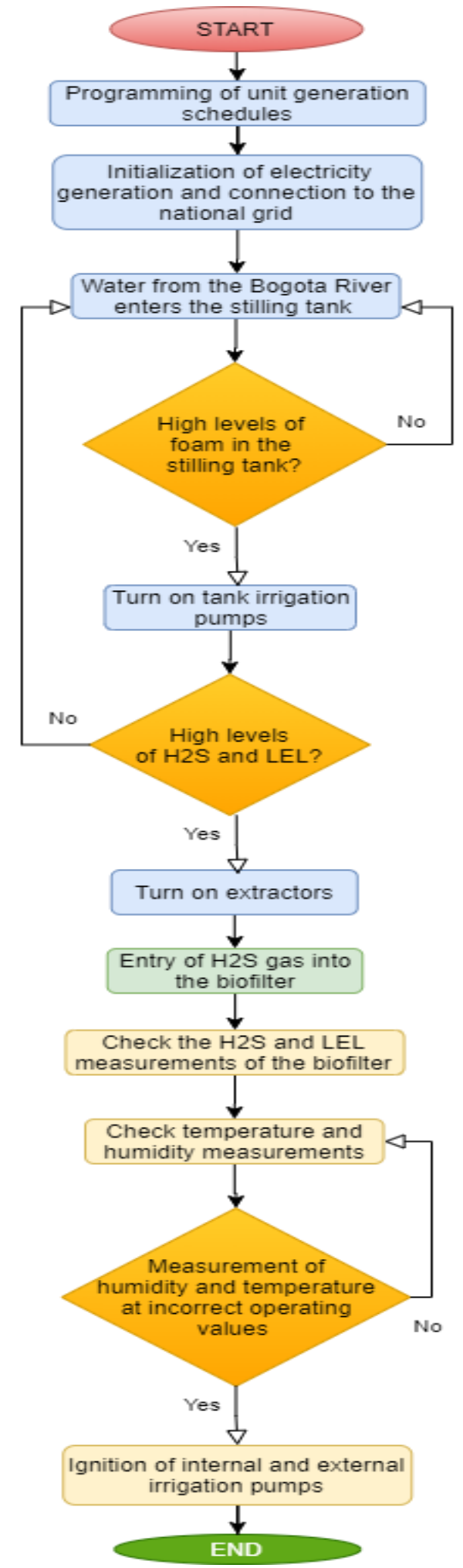

Fig. 1. Flowchart of the hydrogen sulfide extraction process
The automation of this process consisted in the installation of a PLC containing all the control signals for the supervision of the installations containing the concentration of $\mathrm{H} 2 \mathrm{~S}$ and Lower Explosive Limit (LEL) gas in the plant.

\section{II.I Stilling Tank}

The stilling tank is a rectangular structure where the turbine water from the 3 power generation units is received. The tank is 42 meters long, 21 meters wide and 22 meters deep covered by a waterproof canvas tent[1], The water is stored by an operational criterion at certain levels and is then discharged into the Guaca Hydroelectric plant's pipeline where it will be available for electricity generation.

\section{II.I.I Gas extractors}

The stilling tank has four gas extractors with a flow rate of 5300 CFM (cubic feet per minute) to remove the H2S gas in the stilling tank. These extractors are connected to a single pipe from which four branches are detached, one for each bed of the bio-filter as shown in Fig. 2

\section{STILLING TANK AND BIOFILTER}

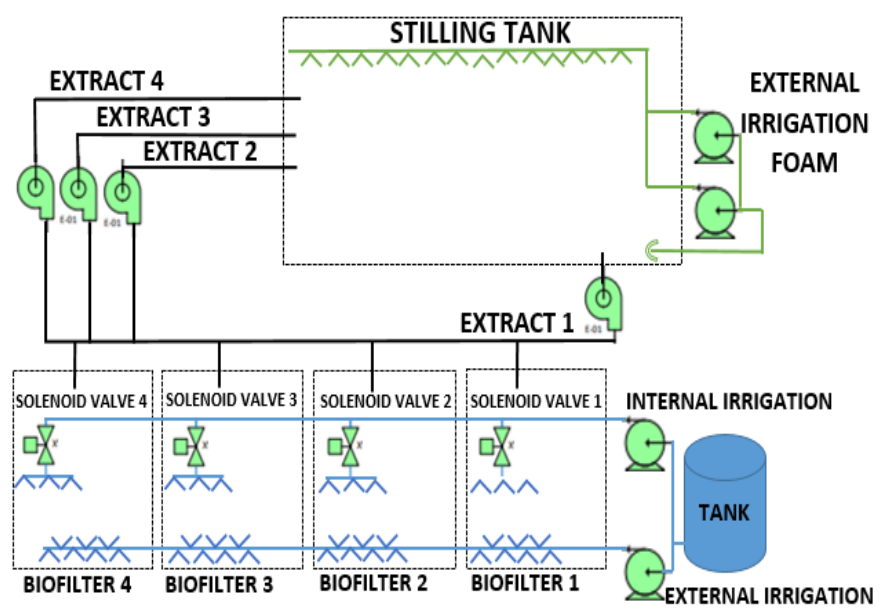

Fig. 2. Arrangement of pumps and solenoid valves

When the gas is extracted from the tank, it enters the bio-filter to be treated by the microorganisms, initiating the decomposition of the gas. The number of extractors to be operated will depend on the number of generating units in operation and the concentration of the H2S gas. Another variable to be monitored is the percentage of LEL explosivity in which for a gas is explosive, under standardized conditions of temperature and pressure, the threshold can be established below which the mixture is not sufficient and therefore there will be no explosion, this being the lower explosive limit [8].

In the stilling tank a 15,000 ppm H2S gas sensor and a $0-100 \%$ range LEL sensor were installed both with 4-20mA output and 20-24 VDV power supply that will keep monitoring the 
International Journal of Engineering Research and Technology. ISSN 0974-3154, Volume 13, Number 10 (2020), pp. 2985-2993

(C) International Research Publication House. https://dx.doi.org/10.37624/IJERT/13.10.2020.2985-2993

normal and/or alarm values as contemplated for good performance so that:

\section{1) Activation of extractors depending on the Generation Units in service}

If you are only going to operate one unit, you have a power switch contact and it turns on the extractor 1 , so that if unit 2 is in operation it turns on the extractor 2 , if unit 3 is in operation it turns on the extractor 3 , i.e. one extractor per unit.

\section{2) Activation of reserve extractor according to $\mathrm{H} 2 \mathrm{~S}$ levels}

Depending on the concentration of the gas in the holding tank and with the other 3 extractors in operation, the fourth extractor, which is a back-up in case of failure or maintenance of one of the other three extractors, must be put into operation if the gas in the tank exceeds values of more than 2,800 parts per million (ppm). After the gas has dropped to $2000 \mathrm{ppm}$ the exhaust fan 4 is turned off.

\section{3) Activation of extractors by high levels of $\mathrm{H} 2 \mathrm{~S}$ with units out of service}

In the event that the generating units are out of service but the $\mathrm{H} 2 \mathrm{~S}$ concentration in the stilling tank is above $500 \mathrm{ppm}$, one or more exhaust fans should be brought into service, until the $\mathrm{H} 2 \mathrm{~S}$ levels are established as normal.

\section{II.I.II Tank Foam Control}

This control system was implemented to avoid the increase of foam levels and overflows in the tank, which is mainly composed of two $12 \mathrm{HP}$ hydraulic pumps that inject water from the same Bogotá river through perforated PVC piping, located around the tank forming a uniformly distributed rain, decreasing the volume of foam.

The measurement of the foam and water levels in the stilling tank is done by two level sensors, the first is ultrasonic contact normally open across the tank and another immersed in the water by atmospheric pressure. For the water level, a low level of 1669 meters above sea level is programmed, which does not allow the tank to be completely emptied, and a maximum level of 1679 meters above sea level, which prevents the tank from being completely filled. The foam level is controlled with a maximum range, which is activated when the foam grows and interrupts the sensor's laser at a value equal to or greater than 1677.3 meters above sea level by energizing the two foam control pumps that start watering the entire surface of the tank to decrease the volume, when the level decreases, the pumps are turned off.

\section{II.II Bio-filter}

The bio-filter of the hydroelectric generation plant is located at an altitude of 1680 meters above sea level and covers an area of $415 \mathrm{~m} 2$ [1]. This is a layer of organic material, typically a mixture of compost and wood chips that support a microbial population. The odorous air that is composed of hydrogen sulfide is forced through this material and converted by the microbes into carbon dioxide, water, mineral salts and biomass [9], formed by the turbination of the Bogotá river used in the generation of electrical energy.

\section{II.II.I Internal conditions Bio-filter}

The mixture made from the compost is $70 \%$ carnation wood compost, $30 \%$ rosewood compost. The net volume of the four beds is $410 \mathrm{~m} 3$, to fill this volume is required approximately 213 tons of the mixture of compost [1] the mixture is uniform, fed with a solution of liquid nutrients and constant humidification, verifying the conditions of moisture and temperature of the substrate, filling it in layers of 20 to $30 \mathrm{~cm}$ to ensure uniformity and in turn a porosity of $50 \%$. The measurements of the degree of acidity $\mathrm{pH}$ of 3-8 [10].

In order for a bio-filter to work efficiently, the media must provide an adequate environment for microbial growth. Therefore, nutrients, temperature and humidity must be provided to the microorganisms for their development and survival [4]. To generate the appropriate conditions in the compost, a polyethylene hose of $1 / 2$ " was installed, which irrigates water with a flow rate of $1.75 \mathrm{gal} / \mathrm{min}$ through a drip system inside the bed. The hose is covered by plastic pallets for protection. The injection of water into each bio-filter bed is controlled by 4 solenoid valves with a flow rate of $0.1-30$ gpm (cubic feet per minute) of water that are controlled by operating time.

Each valve is energized for approximately one minute every 15 minutes. To sustain pressure over the system stroke where a 3 HP pump is installed to irrigate the entire system.

This system was automated with the installation of four hygrostats and four thermostats, powered at 110 volts, a range of 0 to $100 \%$ for humidity and 0 to $60^{\circ} \mathrm{C}$ in temperature, with $\mathrm{NO}$ and NC contacts its IP65 protection, sensors that will be in charge of maintaining the appropriate degree of humidity and temperature, which allows to control the variables of the bio-filter environment [2]. The operational set point is a delta of $60 \%$ to $80 \%$ and a range of $25^{\circ} \mathrm{C}$ to $35^{\circ} \mathrm{C}$, for the relative humidity and temperature respectively, output signals that are programmed to activate the irrigation system if the proposed deltas are not met in order to maintain the operating characteristics of the compost beds.

\section{II.II.II External conditions Bio-filter}

The external irrigation system is made for the irrigation of the biological beds and the humidification of the gas that the biofilter has. Its function is to prevent the formation of cracks in the soil by drying out the biological substrate, either by restoring optimal conditions for humidification (conditions that are lost due to drought or summer in the area or by excessive heating due to bacterial activity).

Taking into account that it is a bio-filter bed that is covered by a thermoplastic Geo-membrane tent that protects it from climatic conditions such as rain and extreme temperatures, in the same way a stable temperature must be maintained on the surface of the bio-filter, being one of the other factors that provide an adequate environment. For this reason a pt100 
thermocouple with a 4-20mA current transducer is installed, which will activate external irrigation on the four bio-filter beds.

The output signal to the PLC activates the pumps as soon as it detects that the temperature measurements exceed $35^{\circ} \mathrm{C}$, watering clean water to the bio-filter and as soon as the temperature is lowered to $25^{\circ} \mathrm{C}$ the order is given to turn it off. The same is done for the relative humidity with a $4-20 \mathrm{~mA}$ transducer and turning on the pumps with a humidity lower than $40 \%$ and turning off the external irrigation system with a humidity of $70 \%$.

Also a timing of the switch on at $8 \mathrm{am}, 11 \mathrm{am}, 2 \mathrm{pm}$ and $7 \mathrm{pm}$ for two minutes trying to keep the system always wet.

\section{II.II.III Irrigation Pumps Operation}

The system is made up of two hydraulic pumps, one of which supplies clean water to the interior of the compost and the other for external watering. This water supply is made up of a series of conduction and irrigation pipes, thick element retention filters that can cause clogging in the pipes and control elements.

The power station has a centrifugal pump fed at $460 \mathrm{Vac}$ in a drawer introduced in a motor control center (MCC) where it starts and stops automatically through a control circuit, this allows the power contacts to be energized.

The energization of the drawer generates that the pumps drive the clean water that is kept in a 5000 liter storage tank through a 1" pipe creating dispersion or rain throughout the Bio-filter.

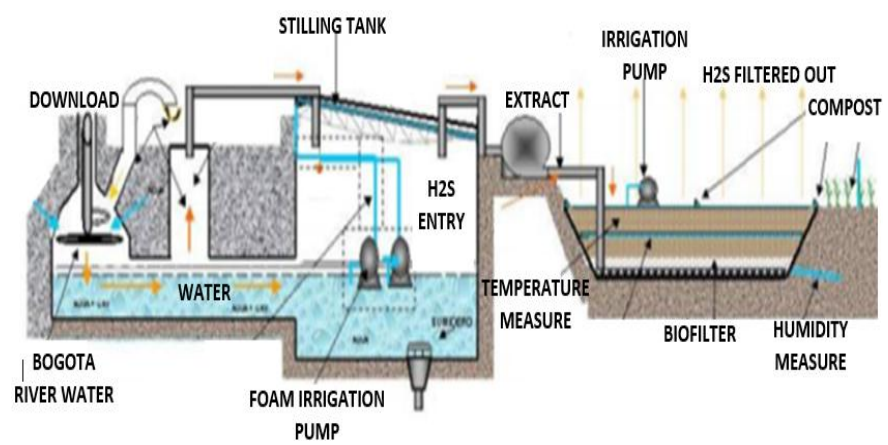

Fig. 3. Biofiltration System Diagram [11]

\section{PROGRAMMABLE LOGIC CONTROLLER (PLC) AUTOMATION SIGNALS}

In the automation of the bio-filter system and the control of the gas extraction system, it was done with the installation of a general electric programmable logic controller with a 24 Vdc power supply. Three 4-20mA current input slots, RTD analog inputs, $10 \mathrm{vdc} / 0-20 \mathrm{~mA}$ analog inputs. Also a slot of analog outputs and a slot of digital outputs accompanied by a modbus communication slot.

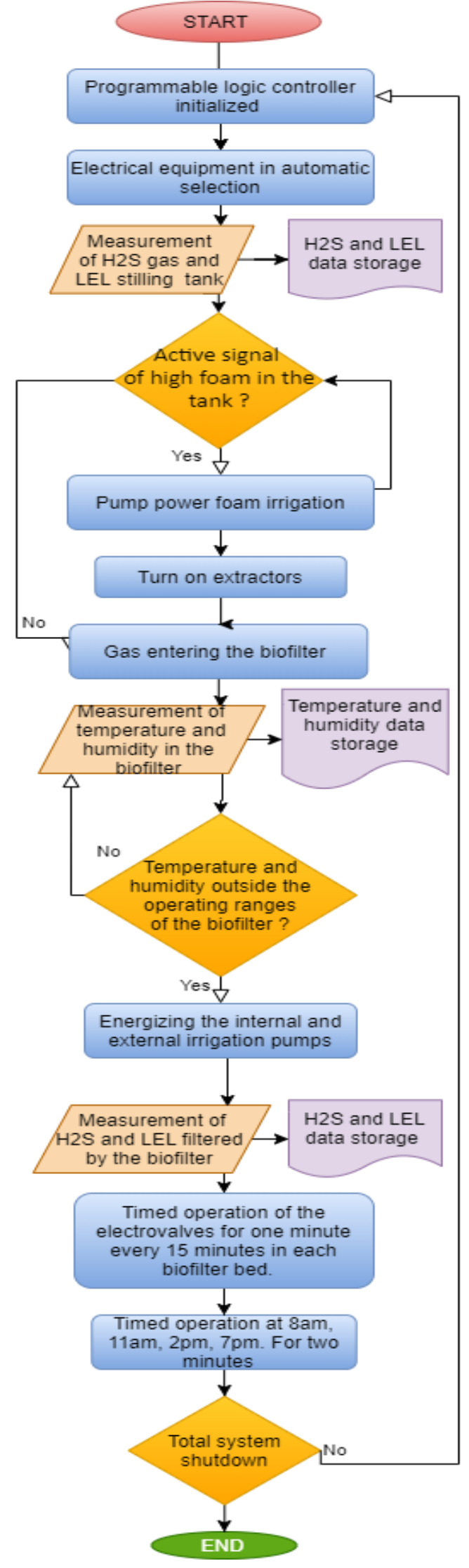

Fig. 4. Process Flowchart of the PLC of in the extraction of hydrogen sulfide 
The PLC was programmed with the software Proficy Machine Edition 9.50, in which its operation was corroborated with the electrical plans and the final tests. Its operation is described below in the flow chart where it is observed that it has three branches the foam control, the automation of the bio-filter and the extraction of the gas from the stilling tank. The PLC was incorporated in a board located in a room called Anchor 19, to which all the signals were taken to control with their operation ranges and their respective alarms announcing if they go out of the limits in which the correct operation of the system is maintained.

Table 1. PLC Signals

\begin{tabular}{|c|c|c|}
\hline \multicolumn{3}{|c|}{ PLC SIGNAL LIST } \\
\hline SERVICE & RANK & ALARMS \\
\hline PPM H2S & 0-15000PPM & $\begin{array}{l}\text { HIGH HIGH } 5000 \text { PPM } \\
\text { HIGH } 3200 \text { PPM }\end{array}$ \\
\hline PPM H2S 1,2,3 & $0-500 \mathrm{PPM}$ & $\begin{array}{l}\text { HIGH HIGH } 150 \text { PPM } \\
\text { HIGH } 80 \text { PPM }\end{array}$ \\
\hline \% LEL1,2,3,4 & 0-100 LEL & $\begin{array}{l}\text { HIGH HIGH } 80 \% \\
\text { HIGH } 70 \\
\end{array}$ \\
\hline $\begin{array}{l}\text { EXTRACTOR } \\
\text { AVAILABILITY } 1,2,3,4\end{array}$ & $\begin{array}{l}\text { AVAILABLE-NOT } \\
\text { AVAILABLE }\end{array}$ & $\begin{array}{l}\text { LOSS OF ENGINE } \\
\text { AVAILABILITY }\end{array}$ \\
\hline $\begin{array}{l}\text { EXTRACTION STATE } \\
1,2,3,4\end{array}$ & ON - OFF & NOT \\
\hline $\begin{array}{l}\text { COMMAND } \\
\text { EXTRACTOR 1,2,3,4 }\end{array}$ & $\mathrm{ON}$ - OFF & NOT \\
\hline $\begin{array}{l}\text { AVAILABILITY } \\
\text { HUMIDIFICATION } \\
\text { PUMP } 1,2\end{array}$ & $\begin{array}{l}\text { A VAILABLE-NOT } \\
\text { AVAILABLE }\end{array}$ & $\begin{array}{l}\text { LOSS OF ENGINE } \\
\text { AVAILABILITY }\end{array}$ \\
\hline $\begin{array}{l}\text { HUMIDIFICATION } \\
\text { PUMP STATUS } 1,2\end{array}$ & ON - OFF & NOT \\
\hline $\begin{array}{l}\text { COMMAND } \\
\text { HUMIDIFICATION } \\
\text { PUMP } 1,2\end{array}$ & ON - OFF & NOT \\
\hline $\begin{array}{l}\text { COMMAND } \\
\text { HUMIDIFICATION } \\
\text { VALVE OPENING } 1,2\end{array}$ & OPEN - CLOSE & NOT \\
\hline $\begin{array}{l}\text { MOISTURE IN CARP } \\
\text { BIOFILTER }\end{array}$ & $0-100 \%$ rh & $\begin{array}{l}\text { LOW HUMIDITY } \\
60 \% \text { LOW }\end{array}$ \\
\hline $\begin{array}{l}\text { MOISTURE IN } \\
\text { BIOFILTER } 1,2 \\
\end{array}$ & $0-100 \%$ rh & $\begin{array}{l}\text { LOW HUMIDITY } \\
60 \% \text { LOW }\end{array}$ \\
\hline $\begin{array}{l}\text { CARP } \\
\text { TEMPERATURE }\end{array}$ & $0-100^{\circ} \mathrm{C}$ & $\begin{array}{l}\text { HIGH } \\
\text { TEMPERATURE } 50^{\circ} \mathrm{C} \\
\text { HIGH } \\
\text { TEMPERATURE } 45^{\circ} \mathrm{C}\end{array}$ \\
\hline $\begin{array}{l}\text { BIOFILTER BED } \\
\text { TEMPERATURE } \\
1,2,3,4\end{array}$ & $0-50^{\circ} \mathrm{C}$ & $\begin{array}{l}\text { HIGH } \\
\text { TEMPERATURE } 40^{\circ} \mathrm{C} \\
\text { HIGH } \\
\text { TEMPERATURE } 35^{\circ} \mathrm{C}\end{array}$ \\
\hline $\begin{array}{l}\text { A VAILABILITY } \\
\text { PUMP CONTROL } \\
\text { FOAM 1,2,3,4 } \\
\end{array}$ & $\begin{array}{l}\text { AVAILABLE-NOT } \\
\text { AVAILABLE }\end{array}$ & $\begin{array}{l}\text { LOSS OF ENGINE } \\
\text { AVAILABILITY }\end{array}$ \\
\hline $\begin{array}{l}\text { FOAM CONTROL } \\
\text { PUMP STATUS } 1,2 \\
\end{array}$ & $\mathrm{ON}$ - OFF & NOT \\
\hline $\begin{array}{l}\text { COMMAND PUMP } \\
\text { CONTROL FOAM } 1,2 \\
\end{array}$ & ON - OFF & NOT \\
\hline $\begin{array}{l}\text { FOAM LEVEL IN } \\
\text { STILLINGTANK }\end{array}$ & $\begin{array}{l}\text { 1668-1677 meters above } \\
\text { sea level }\end{array}$ & $\begin{array}{l}\text { FOAM SENSOR } \\
\text { CONTACT CLOSURE }\end{array}$ \\
\hline
\end{tabular}

\section{ANALYSIS OF SULPHURIC ACID BEHAVIOUR ACCORDING TO CLIMATIC CONDITIONS}

To evidence the results of the automation of the bio-filter system in the hydroelectric generation plant, the data of the variables were measured and stored for a period of 7 months; 2 months were before the automation and 5 months after the automation. Below are the graphs that result in an analysis of the real functioning of the bio-filter taking into account the different climatic conditions that are presented in this area of Colombia being mountainous and therefore provides environments ranging from rain to sunny days [12]. This climatic variation is reflected in the levels of $\mathrm{H} 2 \mathrm{~S}$ gas which decrease or increase according to the climatic state making the $\mathrm{H} 2 \mathrm{~S}$ gas more volatile.

\section{IV.I. Hydrogen sulfide level before doing the automation.}

Fig. 5 and Fig. 6 contain the information about the number of parts per million of $\mathrm{H} 2 \mathrm{~S}$ gas in the bio-filter of the hydroelectric generation plant before the control of the temperature and humidity variables; the data represented are: the average level of hydrogen sulfide (blue surface) and the electricity generation (red bar) according to the corresponding date. When analyzing the overall behavior of hydrogen sulfide in the bio-filter, it can be seen that its behavior is irregular, with growth and decrease intervals according to the schedule of electricity generation at the plant.

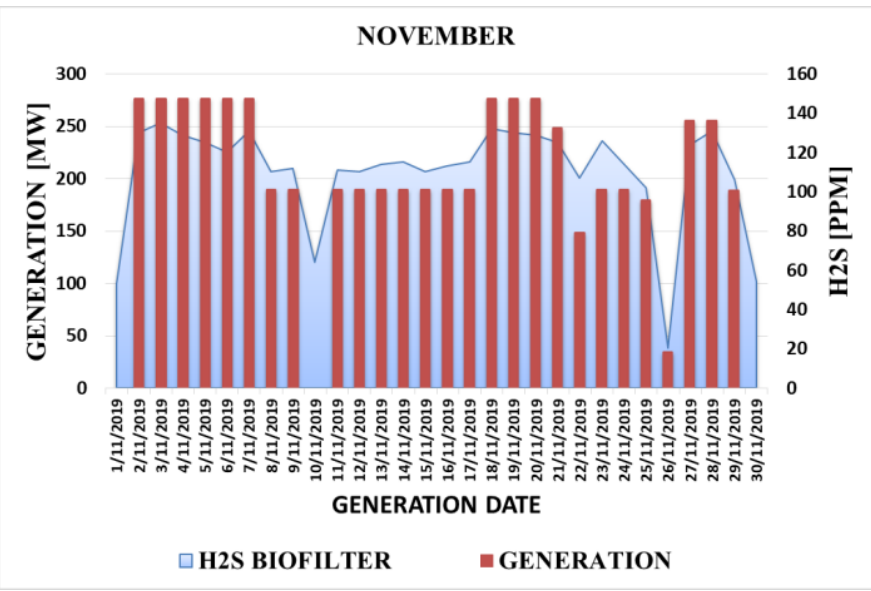

Fig. 5. Hydrogen sulfide level graphs for November 2019 power generation

\section{IV.II. Hydrogen sulfide levels in relation to the state of the climate at the plant}

After the automation performed in the bio-filter the data are stored and downloaded by the system to a PC, which are collected, averaged and graphically represented in order to evidence the behavior of the $\mathrm{H} 2 \mathrm{~S}$ levels measured in the biofilter with respect to the weather conditions in the plant, classified as rain, sunny, cloudy, clear and foggy, weather condition that is recorded by a route that is established to the 
International Journal of Engineering Research and Technology. ISSN 0974-3154, Volume 13, Number 10 (2020), pp. 2985-2993

(C) International Research Publication House. https://dx.doi.org/10.37624/IJERT/13.10.2020.2985-2993

operators on duty, who collect this information along with the power generated.

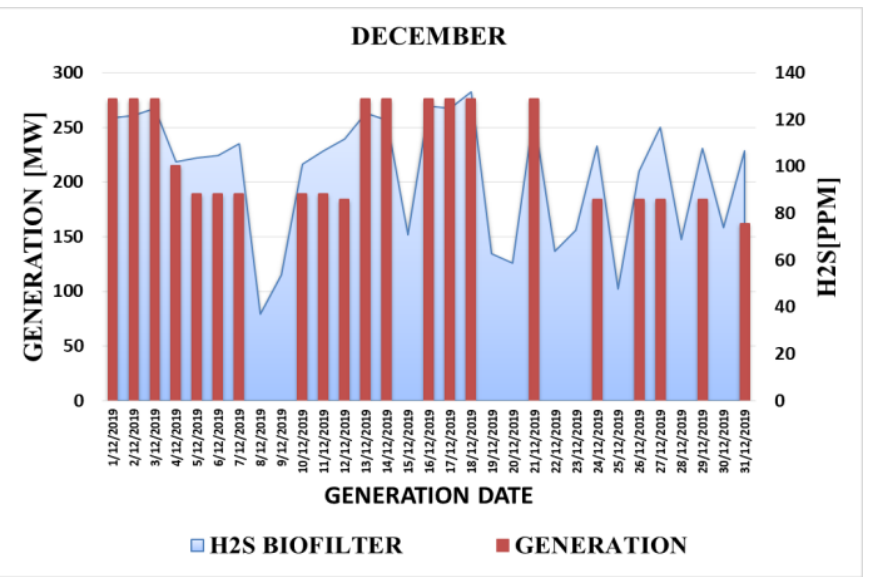

Fig. 6. Hydrogen sulfide levels for December 2019 power generation

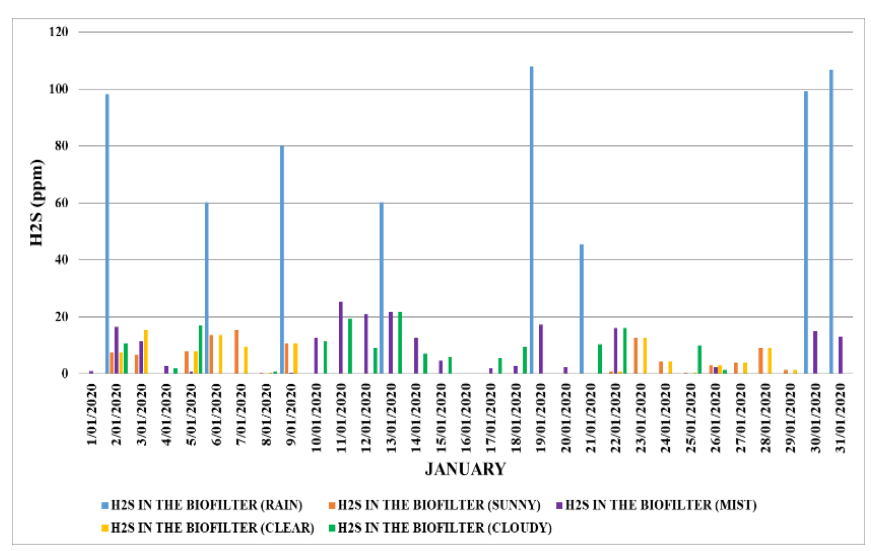

Fig. 7. Levels of hydrogen sulfide in the bio-filter in relation to the state of the climate - January.

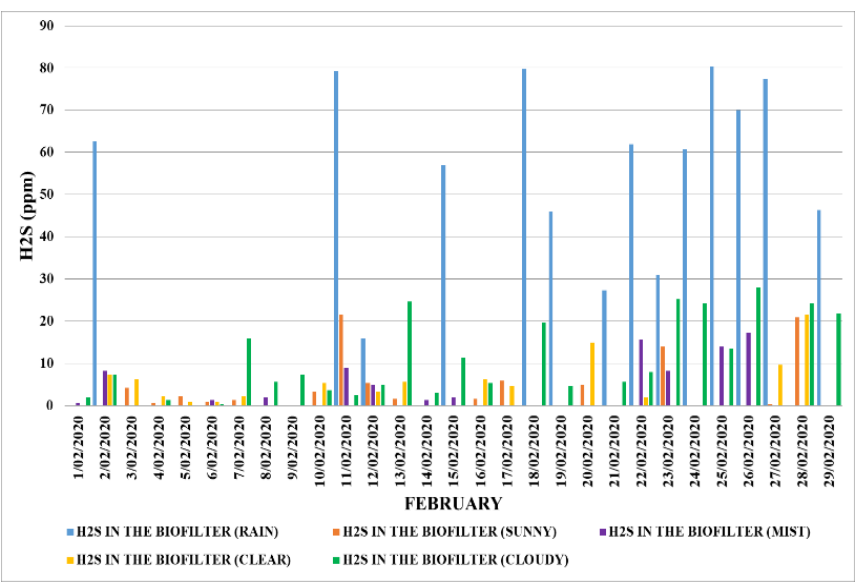

Fig. 8. Levels of hydrogen sulfide in the bio-filter in relation to the state of the climate - February.

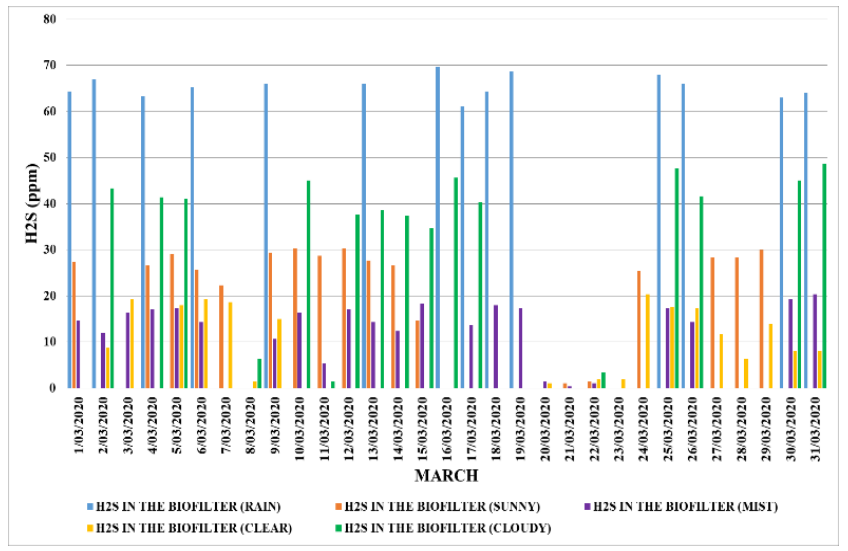

Fig. 9. Levels of hydrogen sulfide in the bio-filter in relation to the state of the climate - March

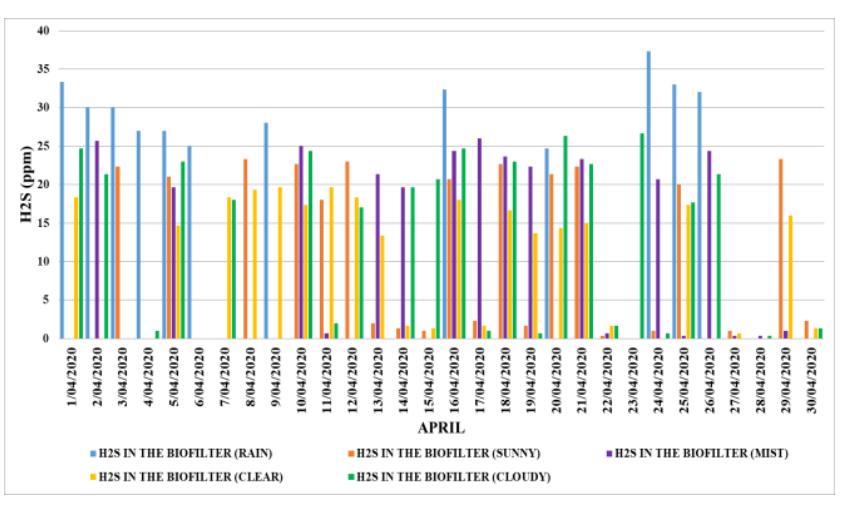

Fig. 10. Levels of hydrogen sulfide in the bio-filter in relation to the state of the climate - April.

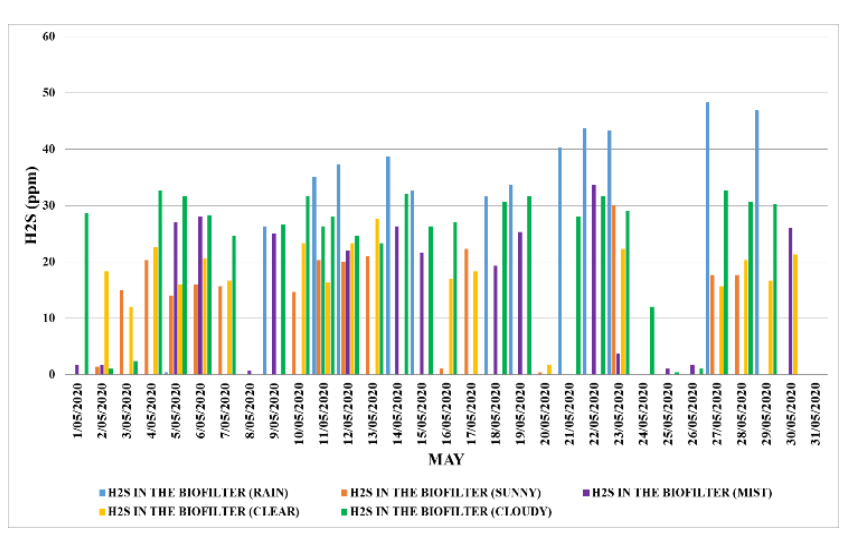

Fig. 11. Levels of hydrogen sulfide in the bio-filter in relation to the state of the climate - May.

When analyzing the behavior of the gas during the five months of study, it can be seen that in the months of january and february the reading of the levels of $\mathrm{H} 2 \mathrm{~S}$ were considerably high in the bio-filter, reaching a maximum of 80 to $100 \mathrm{ppm}$ for rain, contrary to the other states of climate that remain below 40 parts per million of $\mathrm{H} 2 \mathrm{~S}$.

As the data of the following months is analyzed, it can be observed that the gas levels with respect to the rain that are the 
highest show a descendent tendency of $60 \%$ between january and april, diminishing for each month approximately $20 \mathrm{ppm}$, arriving to stabilize during the two last months of study in a range of 30 to $40 \mathrm{ppm}$; on the other hand when doing a global revision of the states of climate remaining the gas levels do not surpass the $30 \mathrm{ppm}$ peak value of the month of march, being maintained below $20 \mathrm{ppm}$ in the four remaining months.

The high levels of $\mathrm{H} 2 \mathrm{~S}$ are a consequence of the movement of hot air that rises due to the rain, which shows a low atmospheric pressure that brings as a consequence that the hydrogen sulfide spreads easily being highly volatile, situation that is perceived in the facilities near the bio-filter since it increases the characteristic smell of "rotten eggs" in the plant.

The number of ppm of H2S in Fig. 5 and Fig. 6 is over 100 ppm; these data indicate that in the first half of 2020, the H2S gas in the bio-filter shows a reduction with respect to the periods of november - december 2019 and in which the most notable decline occurs in the months of april and may 2020 with a percentage of $66.3 \%$ of hydrogen sulfide.

\section{IV.III LEL levels in Stilling Tank}

The values of explosivity that were presented in the bio-filter in the month of january in the hydroelectric power station in their majority surpass the $15 \mathrm{Vol} \%$ and in the tank of stilling they surpass the limits of $25 \mathrm{Vol} \%$, becoming a potential danger for the facilities since by any spark or initiation of fire the tank can be exploded or be ignited, with an aggravating one in which the fire produced by the gas $\mathrm{H} 2 \mathrm{~S}$ is light blue and little visible.

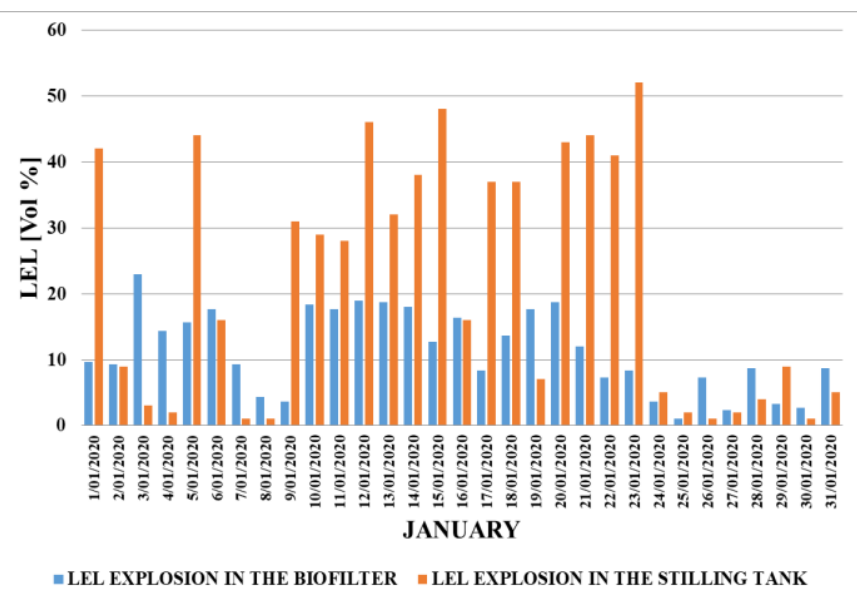

Fig. 12. LEL levels in the bio-filter and stilling tank - January

Knowing that the effects of exposure to $\mathrm{H} 2 \mathrm{~S}$ are a danger to health, both in terms of time of exposure and concentrations in parts per million, it is observed that in the bio-filter, an outdoor installation covered by a geomembrane, the exposure limit of $20 \%$ is approached, in which a smell of gas leakage is perceived and in which some health effect may occur after a few hours. If these levels increase to more than $25 \%$, the first symptom of eye irritation and sore throat may occur [13]. This affects the health and integrity of the workers at the hydroelectric plant.

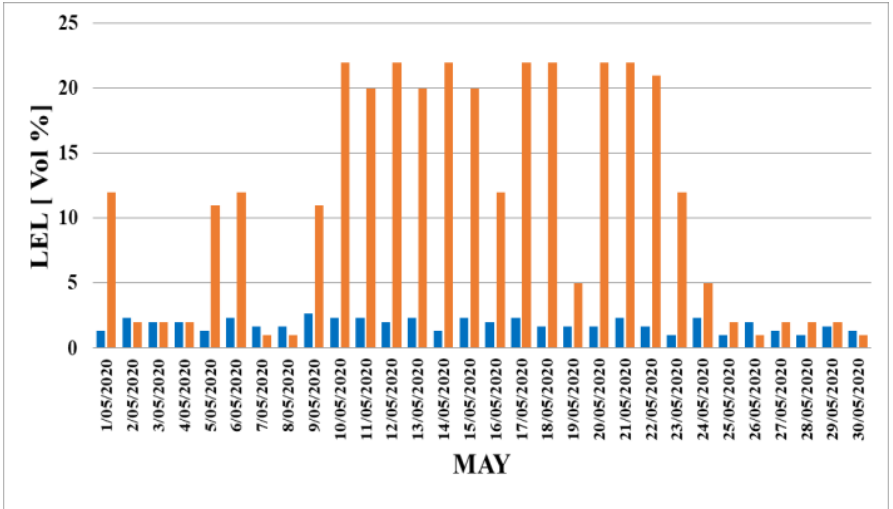

-LEL EXPLOSION IN THE STILLING TANK = LEL EXPLOSION IN THE BIOFILTER

Fig. 13. LEL levels in the bio-filter and stilling tank - May

When comparing the data obtained five months after the implementation of the control in the bio-filter, a reduction of the explosion limits of $85 \%$ is evidenced, due to the fact that the concentration and presence of the hydrogen sulfide decreased notably allowing the improvement of the atmospheric conditions of explosiveness as shown in Fig. 13.

In the stilling tank, a $48 \%$ decrease in the explosion limit is also evident, since the control allowed synchronizing the gas level with the activation of the extractors, improving the performance in the moment of extracting the hydrogen sulfide to the bio-filter, reducing the parts per million of the gas present in the tank.

\section{IV.IV Survey of hydroelectric plant personnel.}

A survey is made to the plant staff during the process of elaboration of the project, verifying in which schedule they have perceived the bad smells?

Table 2. Results of the survey of the hydroelectric plant personnel according to the perception of odours

\begin{tabular}{|l|c|c|}
\hline \multicolumn{1}{|c|}{ TIME } & VOTER TURNOUT & $\%$ \\
\hline 0:00-4:00 am & 12 & 18,5 \\
\hline 4:00-8:00 am & 35 & 53,8 \\
\hline $12: 00-2: 00 \mathrm{pm}$ & 4 & 6,2 \\
\hline 2:00-4:00 pm & 7 & 10,8 \\
\hline 4:00-8:00 pm & 6 & 9,2 \\
\hline 8:00-00:00 & 1 & 1,5 \\
\hline TOTAL & 65 & 100 \\
\hline
\end{tabular}

Where we observed that 65 surveys were conducted representing $100 \%, 1$ worker stated that the time to perceive odors is "8:00 - 12:00 pm" of the night representing 1. 5\%, 12 workers stated that the time to perceive odors is "00:00 - 4:00 $\mathrm{am}$ " in the morning which represents $18.5 \%, 7$ workers stated that the time to perceive odors is "2:00 - 4:00 pm" in the afternoon which represents $10.8 \%, 4$ workers stated that the 
time to perceive odors is "12: $00-2: 00 \mathrm{pm}$ " in the afternoon, which represents $6.2 \%, 6$ workers stated that the time to perceive odors is "4:00 - 8:00 pm" at night, which represents $9.2 \%$ and 35 workers stated that the time to perceive odors is "4:00 - 8:00 am" in the morning, which represents 53.8\%.

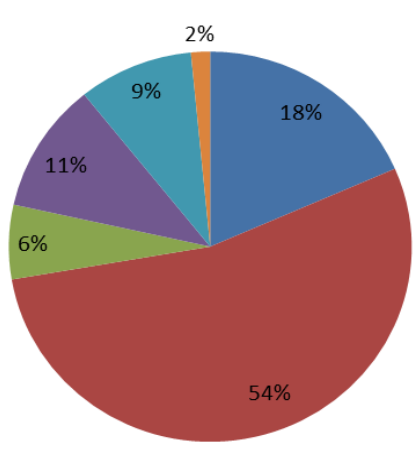

- 0:00- 4:00 am - 4:00-8:00 am $12: 00-2: 00 \mathrm{pm}$ - $2: 00-4: 00 \mathrm{pm}$ - 4:00-8:00 pm 1 8:00-00:00

Fig. 14. Graphs of the percentage of perception of bad smells from the hydroelectric plant at different times

According to those surveyed, we can assure that odors are perceived more at dawn from 4:00 to 8:00 am. This is caused by the phenomenon known as thermal inversion, which is dangerous when there is contamination, since by compressing the layer of cold air to the contaminants against the ground, the concentration of toxic gases can increase by as much as 4 times, and annoying odors can be perceived in the surrounding areas of the plant [14].

When thermal inversion conditions exist and pollutants are emitted into the air, their concentration increases because they are retained, causing air pollution with serious consequences for the health of living beings [6].

\section{RECOMMENDATIONS}

Channel the Bogotá river into its natural course to prevent the dumping of chemicals [15] and the accumulation of waste that can decompose and generate gases such as hydrogen sulfide. The Mayor's Office of Bogotá should also start up a wastewater treatment plant using PTAR saltpetre, which could solve the problem [16] by automating and purifying the waters of the Bogotá river [17].

\section{CONCLUSION}

The operational measurements carried out by the PLC in order to determine the efficiency of the bio-filters and the removal of the hydrogen sulfide over the course of five months, during which time its automation has been working, have shown that it is an efficient control system with a reduction of $\mathrm{H} 2 \mathrm{~S}$ gas of close to $70 \%$ and a reduction of the explosion limits of $85 \%$.

The bio-filtration system is operating under stable conditions as far as the control parameters are concerned (humidity, temperature) recording, in the daily monitoring, values within the optimum ranges for the operation of the bio-filtration system

The programmable logic controller (PLC) was very attractive for the synchronization of the system becoming an innovative idea to control the on, off, opening and closing of electro valves which are part of the proper functioning of the biofilter. With the data obtained by the PLC during the study carried out in the present article, it was possible to evidence the improvement and the efficiency that has to carry out automations with low cost equipment.

Since it allows us to reprogram it, low in energy consumption, it can easily communicate with the computer and also gives us the possibility to store data, which allows us to evaluate the state of the bio-filtration, and estimate how often the change of the compost should be done.

As this research has shown, the levels of hydrogen sulfide gas $(\mathrm{H} 2 \mathrm{~S})$ in the hydroelectric generation plant increase considerably when rainfall occurs. The consequence is that hot air rises and atmospheric pressure falls as a result of gravity on each of the air layers on the earth's surface. When this natural phenomenon occurs, hydrogen sulfide is considerably volatile, and in the event of high exposure and prolonged periods of time it can cause considerable damage to health.

Likewise, the relationship between the programming of electricity generation schedules of the units and the level of hydrogen sulfide in the tank is very relevant. For the transformation of kinetic energy into mechanical energy where the movement of the pelton wheels is introduced, causing a dispersion and conduction of water to the stilling tank, generates a continuous mixing and movement of contaminated water from the Bogotá river increasing the measurements of hydrogen sulfide. Otherwise, when the plant's generation is zero and the water is immobilized, its gas levels do not exceed $3 \mathrm{ppm}$ in the bio-filter.

Without ignoring the high danger of the LEL explosion measures in the facilities, both in the stilling tank and in the bio-filter, a demarcation and signaling of the danger of explosion must be carried out.

The above analysis indicates that a procedure must be followed for all electrical work and/or connections near the holding tank and bio-filter that meet the specifications of the Reglamento Técnico de Instalaciones Eléctricas (RETIEchapter 5) standard for work in areas near fires or explosions [18], taking into account that the results obtained could represent a danger for the worker and the installations.

\section{ACKNOWLEDGEMENTS}

To our families and the Universidad Distrital for given support, as well as to the ENEL- EMGESA personnel who collaborated with important information to make possible the development of the article, especially the electronical engineer JORGE MORENO who authorized us the treatment of used data. 


\section{REFERENCES}

[1] R. Q. Romero and C. D. T. Hernández, "SISTEMA PARA EL CONTROL DE OLORES EN LA CENTRAL HIDROELÉCTRICA EL PARAISO," in Asociación Interamericana de Ingeniería Sanitaria y Ambiental Uruguay, 2006.

[2] N. W. B. Loyola, "Biofiltración con un sistema de tres lechos de compost para la remoción de sulfuro de hidrógeno," FIGEMPA Investig. y Desarro., vol. 1, no. 2 SE-Artículos, Dec. 2017.

[3] K. Vikrant et al., "Biofiltration of hydrogen sulfide: trends and challenges," J. Clean. Prod., vol. 187, pp. 131-147, 2018.

[4] J. M. Morgan-Sagastume and A. N. Robles, "EVALUACIÓN DE UN BIOFILTRO DE COMPOSTA PARA LA ELIMINACIÓN DE H2S DEL AIRE.," 2001.

[5] C. E. Palma-Servín, C. Almaguer-Mejía, R. CárdenasZapata, A. L. Gámez-Anaya, C. Meza-Salgado, and V. M. Ramírez-Hernández, “Análisis de técnicas para la biorremediación de ácido sulfhídrico como contaminante atmosférico en México," 2016.

[6] M. G. Guadalupe, H. U. R. Sánchez, H. U. Godínez, A. Pérez, and S. Arias, "Las inversiones térmicas y la contaminación atmosférica en la Zona Metropolitana de Guadalajara (México)," Investig. geográficas, no. 58, pp. 9-29, 2012.

[7] T. Patel, S. Sheth, and P. Patel, "Design of semiautomatic hydraulic blanking mac[1] T. Patel, S. Sheth, and P. Patel, 'Design of semi-automatic hydraulic blanking machine using PLC,' in National Conference on Innovative \& Emerging Technologies (NCIET-2015), 2015, pp. 410-412.hine using P," in National Conference on Innovative \& Emerging Technologies (NCIET-2015), 2015, pp. 410-412.

[8] I. G. Canale, "Instrumentación en áreas de riesgo explosivo."

[9] D. Schmidt, L. Jacobson, and D. Nicolai, "Bio-filter design information," 2020.

[10] D. Sungthong and D. R. Reinhart, "Control of hydrogen sulfide emissions using autotrophic denitrification landfill biocovers: engineering applications," Front. Environ. Sci. Eng. China, vol. 5, no. 2, pp. 149-158, 2011.

[11] J. Moreno and C. Sutachan, “OPTIMIZACIÓN SISTEMA DE CONTROL DE OLORES EN LA CENTRAL HIDROELÉCTRICA EL PARAÍSO," Universidad de la Salle, 2007.

[12] H. Iriarte, Esta es Colombia, Tercera. 2005.

[13] J. P. López Jara, "Propuesta de procedimiento para trabajo en espacios confinados basados en el monitoreo y evaluación de oxígeno (O2), monóxido de carbono (CO), ácido sulfhídrico (H2S) y límite inferior de explosividad (LEL), en la construcción de esferas de GLP para minim." Universidad de Guayaquil. Facultad de Ingeniería Industrial. Maestría en ..., 2015.

[14] J. M. R. Rincón, A. Bermudez, and T. Rojas, "Contaminación odorífera: causas, efectos y posibles soluciones a una contaminación invisible.," Rev. Investig. Agrar. y Ambient., vol. 9, no. 1, pp. 165-180, 2018.

[15] L. A. Artuz, M. S. Martínez, and C. J. Morales, "Las industrias curtiembres y su incidencia en la contaminación del río Bogotá," Isocuanta, vol. 1, no. $1,2011$.

[16] A. F. Villalba Cusba, "Ejecución y Supervisión del Montaje de la Fase I de la PTAR Salitre para Suministro e Instalación de Equipos, Procesos de Instrumentación y Automatización-PTAR Salitre," 2020.

[17] J. L. Tique Horta and J. S. Poveda Buendía, "Consecuencias de las decisiones de orden administrativo en el proceso de saneamiento del Río Bogotá.” Universidad La Gran Colombia, 2015.

[18] M. Md, "Reglamento técnico de instalaciones eléctricas," Bogotá DC, vol. 708, 2013. 